\title{
Developing Nations and Developing Surveys: Measuring Inner Wellbeing in Zambia and India, 2010-2013 ${ }^{1}$
}

\author{
Stanley O. Gaines, Jr. \\ (Stanley.Gaines@brunel.ac.uk) \\ Brunel University, United Kingdom \\ Sarah C. White \\ University of Bath, United Kingdom
}

\begin{abstract}
In the present chapter, we summarize the results of a programme of research that we have undertaken concerning domains of inner wellbeing (i.e., individuals' feelings and thoughts about what they can do and be) as experienced by individuals in villages within two nations in the global South (i.e., Zambia and India). Results of confirmatory factor analyses for Zambia at Time 1 (in 2010, $n=361$ ) and for India at Time 1 (in 2011, n = 287) indicated that, although we had expected seven to eight intercorrelated domains to emerge, inner wellbeing was best regarded as a unidimensional construct. However, after we engaged in intensive reflection and extensive reconceptualization and measurement of inner wellbeing, results for Zambia Time 2 (in 2012, $n=344$ ) and for India Time 2 (in 2013, $n=335$ ) indicated that inner wellbeing was best regarded as a multidimensional construct with seven intercorrelated domains (i.e., economic confidence, agency/participation, social connections, close relationships, physical/mental health, competence/selfworth, and values/meaning). Implications for the conceptualization and measurement of inner wellbeing within the global South, and for theoretical and methodological issues concerning wellbeing in general, are discussed.
\end{abstract}

\section{Introduction}

According to Ryan and Deci (2001), wellbeing is "optimal psychological functioning and experience" (p. 142). Within the global West, wellbeing frequently is regarded as an intrapersonal construct that transcends social contexts. However, within as well as outside the global West, individuals' actual experience of wellbeing is most accurately regarded as inherently interpersonal (see Leary, 2007). At least one psychological theory from the global West (i.e., self-determination theory; Ryan \& Deci, 2000) posits that relatedness is a primary psychological need, alongside autonomy and competence; we would argue that outside the global West, the interpersonal roots of wellbeing are even more obvious aspects of individuals' daily lives.

Since the mid-to-late 1980s, two major approaches to conceptualizing and measuring wellbeing as an individual-difference construct within the global West have emerged: (1) Subjective wellbeing (i.e., the degree to which individuals think and feel positively toward their lives), measured by two independently derived surveys (i.e., the Satisfaction with Life Scale, created by Diener, Emmons, Larsen, \& Griffin, 1985; and the Positive \& Negative Affect Schedule, created by Watson, Clark, \& Tellegen, 1988); and (2) psychological wellbeing (i.e., the degree to which individuals believe that they have obtained meaning in their lives), measured by one multi-dimensional survey (unnamed and unpublished in full form, but nonetheless created by Ryff, 1989). According to Ryan and Deci (2001), Diener's concept of subjective wellbeing reflects an hedonic perspective; whereas Ryff's concept of psychological wellbeing reflects an eudaimonic perspective. Although Diener (e.g., Oishi, Diener, D.-W. Choi, Kim-Prieto, \& I. Choi, 2007) and Ryff (e.g., Karasawa, Curhan, Markus, Kitayama, Love, Radler, \& Ryff, 2011) have extended their research beyond the global West, neither subjective wellbeing nor psychological wellbeing originated from research outside the global West.

1 Preparation of the present chapter was facilitated by Economic and Social Research Council/Department for International Development Joint Scheme for Research on International Development (Poverty Alleviation) grant number RES-167-25-0507 ES/ $\mathrm{H} 033769 / 1$. 
Several alternative approaches to conceptualizing and measuring wellbeing have arisen outside the global West (for a review, see White, Gaines, \& Jha, 2012). Particularly relevant to the present chapter is White's (2009) conceptualization and proposed measurement of inner wellbeing (i.e., individuals' feelings and thoughts about what they can do and be) within the global South. Based on the results of qualitative research that she conducted in Zambia in 2009, White proposed that inner wellbeing is a construct with several distinct, yet interrelated, dimensions. In the present chapter, we report the results of a three-year study (2010-13) - influenced by White's aforementioned work - concerning inner wellbeing among individuals in two developing nations within the global South - namely, Zambia and India. As will become evident shortly, although we began with White's conceptualization and measurement of inner wellbeing, we gradually changed our conceptualization and (especially) measurement of the domains of inner wellbeing across time in both nations.

\section{Zambia, Time 1 (2010): Attempted Replication of White's (2009) Conceptualization and Measure- ment of Inner Wellbeing}

In 2010, members of the Wellbeing and Poverty Pathways Project team went to Zambia with the goal of conceptualizing and measuring inner wellbeing as White (2009) had done previously. White developed a prototypical, 50-item survey of inner wellbeing that was designed to measure individual differences along seven interrelated domains: (1) Access to resources (12 items; sample item: "There are times in each year where I have to struggle to make ends meet"); (2) agency/participation (6 items; sample item: "I can make a difference to my community when I work with others"); (3) social connections (6 items; sample item: "I have people I can go to for help and advice"); (4) close relationships (6 items; sample item: "I have to take too much responsibility for the running of our household," to be reverse-scored); (5) physical/mental health (9 items; sample item: "I get enough good quality food"); (6) competence/self-worth (6 items; sample item: "I am able to do things which help other people"); and (7) values/meaning (5 items; sample item: "I worry that our community doesn't live according to God's laws," to be reverse-scored). Within each domain, individuals were to be given a set of declaratory statements and were asked to indicate (a) whether they agreed or disagreed with each statement and (b) whether they strongly agreed or disagreed with each statement. At the time, however, White did not administer the prototype survey. Thus, information concerning the validity and reliability of White's prototype survey is not available.

When we applied a revised version of White's questionnaire (six items per domain) to participants in Zambia at Time $1(n=361)$, we encountered numerous instances of severe non-normality (i.e., skewness and kurtosis values exceeding 2.30 in absolute value; see Lei \& Lomax, 2005) that initially prevented us from testing White's seven-factor intercorrelated model of domains of inner wellbeing. By normalizing all item scores (i.e., converting the raw scores into standardized $z$ scores so that for all items, the mean is .00 and the standard deviation is 1.00; see Mels, 2006) via PRELIS 9.1 (the pre-processor complement to LISREL 9.1; Jöreskog \& Sörbom, 2012b), we were able to eliminate most (but not all) instances of severe non-normality in item score distributions. In turn, by eliminating most instances of severe non-normality, we were able to calculate a matrix of zero-order correlations among item scores via PRELIS 9.1 for entry into confirmatory factor analyses via maximum likelihood solutions (and invoking the ridge option and ridge constant; see Jöreskog, Sörbom, du Toit, \& du Toit, 2001) in LISREL 9.1 (Jöreskog \& Sörbom, 2012a). (We do not report results using robust maximum likelihood solutions, which required computing asymptotic covariance matrices and resulted in models that consistently failed to fit the data; see Jöreskog \& Sörbom, 1996a, b, concerning the advantages and disadvantages of using asymptotic covariance matrices.)

Results of confirmatory factor analyses (details of which are also reported in Gaines \& White, 2013) indicated that the best-fitting linear model (based on $\chi^{2}, \chi^{2} / d f$, SRMSR, and AGFI as goodness-of-fit statistics; see Brown, 2006) was not an intercorrelated seven-factor model (for which we could not obtain a solution), or even an uncorrelated seven-factor model (for which we could obtain a solution; $\chi^{2}=532.49, d f=854$, NS; $\chi^{2}$ / $d f=.54$; SRMSR $=.05$; AGFI = .92), but rather a unifactorial model (for which we could obtain a solution; $\chi^{2}=467.45, d f=860, n s ; \chi^{2} / d f=.54 ;$ SRMSR $=.04$; adjusted goodness-of-fit index $=.93$ ). (We also attempted to test the goodness-of-fit of categorical models but consistently failed to obtain solutions, regardless of num- 
ber of factors or correlations among factors; see Jöreskog \& Sörbom, 1996a, b, concerning the advantages and disadvantages of categorical models). For the unifactorial model, 24 of the 42 loadings were positive, with 16 of those items reaching significance ( $p s<.05$ or lower) or approaching significance ( $p s<.10$ ); yet 18 of the 42 loadings were negative (even after reverse-worded items were rescored so that higher scores should reflect higher levels of inner wellbeing), with 6 were reaching or approaching significance. In light of these results, we found it necessary to completely revise White's original measure of inner wellbeing; yet we did not dismiss White's model, out of concern that the format and content of the original items did not allow us to conduct fair tests of the model.

\section{India, Time 1 (2011): Completely Revamped Survey, Slightly Revamped Model}

In 2011, members of the Wellbeing and Poverty Pathways Project team went to India with the goal of conceptualizing inner wellbeing in a somewhat different manner, and measuring inner wellbeing in a dramatically different manner, than we had done in Zambia during the previous year. The less-than-encouraging results that we obtained for Zambia Time 1 prompted us to reflect at length upon our conceptualization and measurement of inner wellbeing. White, Gaines, and Jha (2012) summarized the evolution of the survey as follows:

Faced with general questions ('Do you have people who help you in times of need?') people asked for specific examples ('What kinds of need do you mean?'). Faced with abstract terms, they sought to bring them down to earth. This made us realize that what seems straightforward and self-evident in one context [e.g., university settings with Psychology undergraduates as participants] might not be so in another [e.g., village settings with participants who generally had not enjoyed the benefits of university education], that the wellbeing approaches assume a culture of questioning that is by no means generally shared (p. 772).

For India Time 1 ( $n=287)$, we divided White's (2009) access to resources domain into the separate domains of enabling environment and economic confidence; and we retained White's agency/participation, social connections, close relationships, physical/mental health, competence/self-worth, and values/meaning domains. Also, we made the items more concrete (i.e., less abstract) than we had done previously. Finally, rather than present a list of declarative statements with agree-disagree scale format, we presented a list of questions (four items per domain) with scales that offered gradations of responses.

We encountered some instances of non-normality of item scale distributions for India Time 1, though not nearly as numerous as the instances that we had found for Zambia Time 1. Nevertheless, we normalized all item scores and calculated a zero-order correlation matrix in PRELIS 9.1; and we entered the matrix into confirmatory factor analyses (again using maximum likelihood method, ridge option, and ridge constant) using LISREL 9.1. (We do not report results using robust maximum likelihood solutions, which required computing asymptotic covariance matrices and resulted in models that consistently failed to fit the data.)

Results of confirmatory factor analyses (also reported in White, Gaines, \& Jha, 2013) indicated that the best-fitting linear model was not an intercorrelated eight-factor model (for which we could not obtain a solution), or even an uncorrelated eight-factor model (for which we could obtain a solution; $\chi^{2}=384.64, d f=$ $488, n s ; \chi^{2} / d f=.79 ;$ SRMSR $=.07$; AGFI $=.90$ ), but rather a unifactorial model (for which we could obtain a solution; $\chi^{2}=262.24, d f=495, n s ; \chi^{2} / d f=.53$; SRMSR $=.04$; AGFI $=.93$ ). (We also attempted to test the goodness-of-fit of categorical models but consistently failed to obtain solutions, regardless of number of factors or correlations among factors.) For the unifactorial model, a majority of the items loaded significantly to marginally, and all items loaded positively (after reverse-worded items were rescored), on their hypothesized domains, except for the domain of enabling environment. Overall, results for India Time 1 were encouraging for our slightly revised model and wholly revised survey measuring interrelated domains of inner wellbeing, though it became clear that the domain of enabling environment was problematic.

\section{Zambia, Time 2 (2012): Slightly Revamped Model, Slightly Revamped Survey}

In 2012, members of the Wellbeing and Poverty Pathways Project team went back to Zambia with a seven-domain, intercorrelated-factor model (i.e., economic confidence, agency/participation, social connections, close relationships, physical/mental health, competence/self-worth, and values/meaning; in the wake of problematic results, we dropped the domain of enabling environment) and slightly revised survey (five items per 
domain, and taking into account local conditions for Zambia as distinct from local conditions in India), compared to the model and survey that we used in India Time 2, keeping in mind that the survey in particular was quite different from the survey that we had used in Zambia Time 1. We did not find any instances of non-normality in item score distributions for Zambia Time $2(n=344)$. Thus, we were able to calculate the zero-order correlation matrix in PRELIS 9.1 for entry into LISREL 9.1 (again using maximum likelihood method, ridge option, and ridge constant) without having to normalize item scores in advance. (We do not report results using robust maximum likelihood solutions, which required computing asymptotic covariance matrices and resulted in models that consistently failed to fit the data.)

Results of the confirmatory factor analyses concerning linear models (also reported in Gaines \& White, $2013)$ indicated that a seven-domain, intercorrelated factor model $\left(\chi^{2}=231.06, d f=567, N S ; \chi^{2} / d f=.41\right.$; $\mathrm{SRMSR}=.03 ; \mathrm{AGFI}=.96)$ provided significantly better fit than did either a seven-domain, uncorrelated factor model $\left(\chi^{2}=531.54, d f=588, n s ; \chi^{2} / d f=.90 ;\right.$ SRMSR $=.08$; adjusted goodness-of-fit index $\left.=.89\right)$ or a unifactorial model $\left(\chi^{2}=289.96, d f=594, n s ; \chi^{2} / d f=.49\right.$; SRMSR $=.04$; AGFI $\left.=.95\right)$. (We also attempted to test the goodness-of-fit of categorical models but consistently failed to obtain solutions, regardless of number of factors or correlations among factors.) For the seven-factor intercorrelated model, all but one of the items loaded significantly to marginally, and positively (after reverse-worded items were rescored), on the hypothesized domain. In addition, all seven domains were represented within the correlated factor structure. Taken as a whole, results for Zambia Time 2 indicated that we had developed a survey possessing high construct validity (see Nunnally \& Bernstein, 1994). As such, we present the full Zambia Time 2 survey in Table 1 (all Tables are printed at the end of the chapter).

\section{India, Time 2 (2013): Same Model, Slightly Revamped Survey}

Finally, members of the Wellbeing and Poverty Pathways Project team went back to India in 2013, with the same seven-domain, intercorrelated-factor model (i.e., economic confidence, agency/participation, social connections, close relationships, physical/mental health, competence/self-worth, and values/meaning) and slightly different survey (five items per domains, and taking into account local conditions in India as distinct from local conditions in Zambia) compared to Zambia Time 2, keeping in mind that both the model and the survey that we used in India Time 2 were somewhat different from the model and survey that we had used in India Time 1. We encountered approximately the same number of instances of non-normality for India Time $2(n=335)$ as we did for India Time 1. Hence, prior to calculating a zero-order correlation matrix in PRELIS 9.1 for entry into confirmatory factor analyses (again using maximum likelihood method, ridge option, and ridge constant) in LISREL 9.1, we found it necessary to normalize item scores in advance via PRELIS 9.1. (We do not report results using robust maximum likelihood solutions, which required computing asymptotic covariance matrices and resulted in models that consistently failed to fit the data.)

Results of confirmatory factor analyses concerning linear models (also reported in White, Gaines, \& Jha, 2013) indicated that a seven-domain, intercorrelated-factor model $\left(\chi^{2}=288.95, d f=567, N S ; \chi^{2} / d f=\right.$ .51 ; SRMSR $=.04$; adjusted goodness-of-fit index $=.94)$ provided significantly better fit to the data then did either a seven-domain, uncorrelated factor $\left(\chi^{2}=544.33, d f=588, N S ; \chi^{2} / d f=.93\right.$; SRMSR $=.08$; adjusted goodness-of-fit index $=.88)$ model or a unifactorial model $\left(\chi^{2}=384.43, d f=594, N S ; \chi^{2} / d f=.65 ;\right.$ SRMSR $=$ .05 ; adjusted goodness-of-fit index $=.92$ ). (We also attempted to test the goodness-of-fit of categorical models but consistently failed to obtain solutions, regardless of number of factors or correlations among factors.) For the seven-factor intercorrelated model, all items loaded significantly to marginally, and positively (after reverse-worded items were rescored), on the hypothesized domain; and all seven domains were represented. As was the case for Zambia Time 2, results for India Time 2 indicated that the survey possessed high construct validity. Therefore, we present the full India Time 2 survey in Table 2.

\section{Concluding Thoughts}

Throughout the present chapter, we have focused on construct validity as a psychometric issue. However, a related yet distinct issue that we have not addressed so far is reliability of lack of measurement error (Nunnal- 
ly \& Bernstein, 1994). Even with the surveys for Zambia Time 2 and India Time 2, the small number of items made it impossible for us to consistently obtain Cronbach's alphas of .70 or above. Thus, we recommend that future researchers attempt to double the number of items that we used in both nations at Time 2 (i.e., increase the number of items per scale from five to ten).

Earlier in the present chapter, we addressed the theme of conceptualizing and measuring wellbeing in the global South versus the global West. Our conceptualization and measurement of inner wellbeing, developed in response to White's (2009) earlier work in Zambia, are notable for their dissimilarity to Diener's dominant conceptualization and measurement of subjective wellbeing (e.g., Diener, Oishi, \& Lucas, 2003). By the same token, our conceptualization (if not our measurement) of inner wellbeing bears some resemblance to Ryff's influential conceptualization and measurement of psychological wellbeing (e.g., Ryff \& Singer, 2006) - an approach that, in turn, Ryan and Deci (2001) viewed as compatible with their self-determination theory (Ryan $\&$ Deci, 2000). We strongly encourage future researchers to compare and contrast these three approaches (and their relative compatibility with self-determination theory) in cross-cultural research on wellbeing.

In closing, we return to the theme of wellbeing as an inherently interpersonal construct. One of the major challenges that we faced as researchers from the global West, conceptualizing and measuring wellbeing in the global South, was immersing ourselves sufficiently within the social contexts of villages in Zambia and India to emerge with culturally embedded constructs of the domains of inner wellbeing. We believe that the results of the present programme of research affirm that we have striven toward (and, hopefully, we have succeeded in) meeting such a challenge.

\section{References}

Brown, T. A. (2006). Confirmatory factor analysis for applied research. New York, NY: Guilford Press.

Diener, E., Emmons, R. A., Larsen, R. J., \& Griffin, S. (1985). The Satisfaction with Life Scale. Journal of Personality Assessment, 49, 71-75.

Diener, E., Oishi, S., \& Lucas, R. E. (2003). Personality, culture, and subjective well-being: Emotional and cognitive evaluations of life. Annual Review of Psychology, 54, 403-425.

Gaines, S. O., Jr., \& White, S. C. (2013). Evolution of a survey: Conceptualising and measuring inner wellbeing among individuals in Zambia, 2010-2012. Unpublished manuscript.

Jöreskog, K. G., \& Sorbom, D. (1996a). LISREL 8: User's reference guide. Chicago, IL: Scientific Software International. Jöreskog, K. G., \& Sorbom, D. (1996b). PRELIS 2: User's reference guide. Chicago, IL: Scientific Software International. Jöreskog, K. G., \& Sorbom, D. (2012a). LISREL 9.1 [Computer software]. Lincolnwood, IL: Scientific Software International.

Jöreskog, K. G., \& Sorbom, D. (2012b). PRELIS 9.1 [Computer software]. Lincolnwood, IL: Scientific Software International.

Jöreskog, K. G., Sorbom, D., du Toit, S. H. C., \& du Toit, M. (2001). LISREL 8: New statistical features. Lincolnwood, IL: Scientific Software International.

Karasawa, M., Curhan, K. B., Markus, H. R., Kitayama, S. S., Love, G. D., Radler, B. T., \& Ryff, C. D. (2011). Cultural perspectives on aging and well-being: A comparison between Japan and the US. International Journal of Aging \& Human Development, 73, 73-98.

Leary, M. (2007). Motivational and emotional aspects of the self. Annual Review of Psychology, 58, 317-344.

Lei, M., \& Lomax, R. G. (2005). The effect of varying degrees of nonnormality in structural equation modelling. Structural Equation Modeling, 12, 1-27.

Mels, G. (2006). LISREL for Windows: Getting started guide. Lincolnwood, IL: Scientific Software International.

Nunnally, J. C., \& Bernstein, I. H. (1994). Psychometric theory (3rd ed.). New York, NY: McGraw-Hill.

Oishi, S., Diener, E., Choi, D. W., Kim-Prieto, C., \& Choi, I. (2007). The dynamics of daily events and well-being across cultures: When less is more. Journal of Personality and Social Psychology, 93, 685-698.

Ryan, R. M., \& Deci, E. L. (2000). Self-determination theory and the facilitation of intrinsic motivation, social development, and well-being. American Psychologist, 55, 68-78. 
Ryan, R. M., \& Deci, E. L. (2001). On happiness and human potentials: A review of research on hedonic and eudaimonic well-being. Annual Review of Psychology, 52, 141-166.

Ryff, C. D. (1989). Happiness is everything, or is it? Explorations on the meaning of psychological well-being. Journal of Personality and Social Psychology, 57, 1069-1081.

Ryff, C. D., \& Singer, B. H. (2006). Know thyself and become what you are: A eudaimonic approach to psychological well-being. Journal of Happiness Studies, 9, 13-39.

Watson, D., Clark, L. A., \& Tellegen, A. (1988). Development and validation of brief measures of positive and negative affect: The PANAS scales. Journal of Personality and Social Psychology, 54, 1063-1070.

White, S. C. (2009). Bringing wellbeing into development practice. Bath, United Kingdom: University of Bath/Wellbeing in Developing Countries Research Group (WeD Working Paper 09/50).

White, S. C., Gaines, S. O., Jr., \& Jha, S. (2012). Beyond subjective well-being: A critical review of the Stiglitz report approach to subjective perspectives on quality of life. Journal of International Development, 24, 763-776.

White, S. C., Gaines S. O., Jr., \& Jha, S. (2013). Inner wellbeing: Concept and validation of a new approach to subjective perceptions of wellbeing - India. Social Indicators Research.

\section{Table 1.}

Set of Items Measuring Dimensions of Inner Wellbeing, Zambia Time

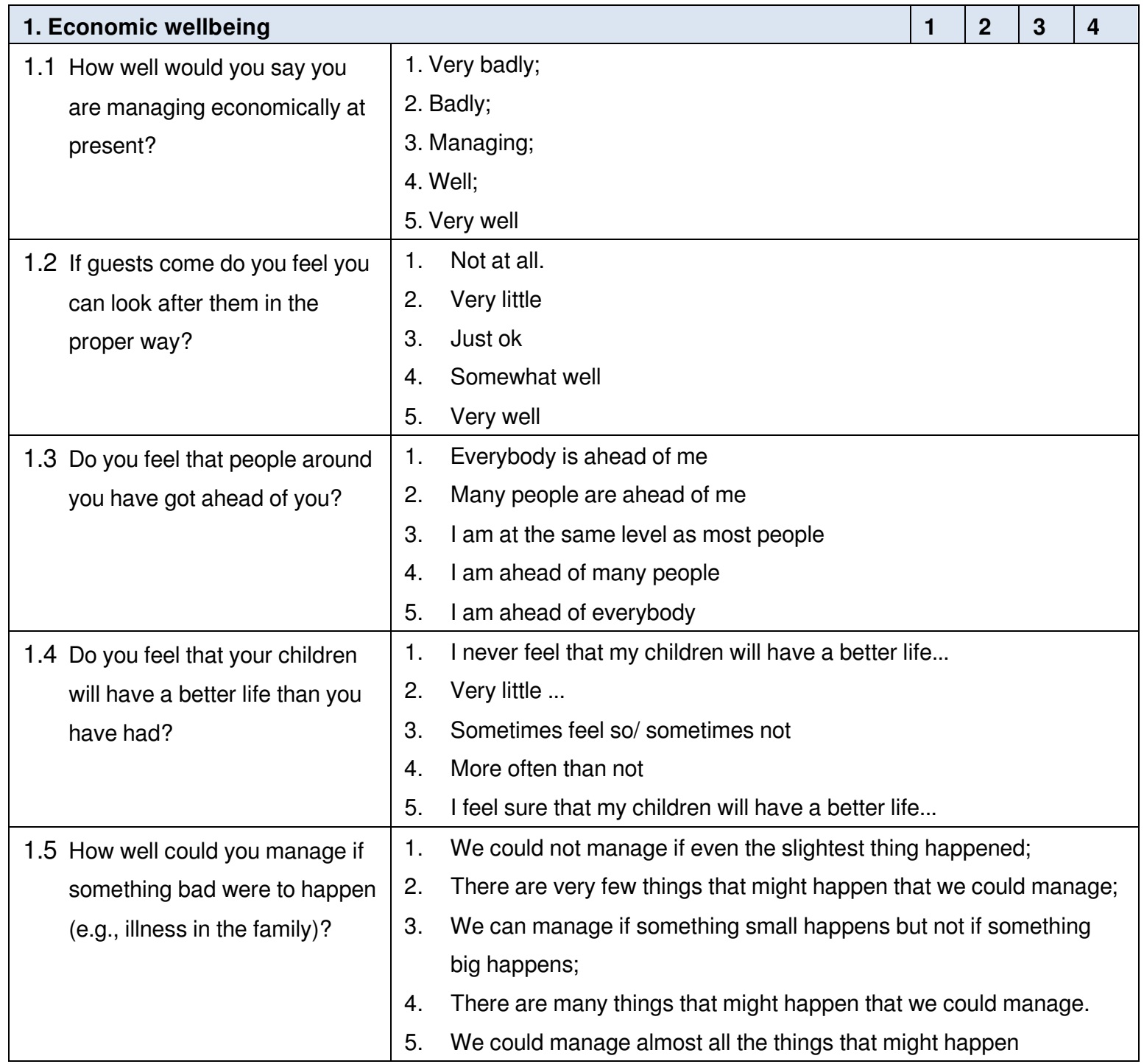




\begin{tabular}{|c|c|}
\hline 2. Havi & \\
\hline $\begin{array}{l}2.1 \text { If there is a village meeting do } \\
\text { you have an opportunity to } \\
\text { voice your opinion? }\end{array}$ & $\begin{array}{l}\text { 1. I never get the opportunity to speak } \\
\text { 2. More often than not I am denied the opportunity to speak. } \\
\text { 3. I sometimes get the opportunity to speak and sometimes do not } \\
\text { 4. I get an opportunity to speak more than half the time } \\
\text { 5. I always get the opportunity to speak }\end{array}$ \\
\hline $\begin{array}{l}2.2 \text { If official decisions are made } \\
\text { that affect you badly, do you } \\
\text { feel that you have power to } \\
\text { change them? }\end{array}$ & $\begin{array}{l}\text { 1. I never feel that I can make a change } \\
\text { 2. It is only on few occasions that I feel can make a change } \\
\text { 3. I sometimes feel I can make a change and sometimes not } \\
\text { 4. More often than not I feel can make a change } \\
\text { 5. I always feel that I can make a change }\end{array}$ \\
\hline $\begin{array}{l}\text { 2.3 Do feel that you are heard? } \\
\text { (Beyond family - that listened } \\
\text { to seriously, not necessarily } \\
\text { that people do what you say) }\end{array}$ & $\begin{array}{l}\text { 1. Never } \\
\text { 2. Very little of the time } \\
\text { 3. Sometimes yes, sometimes no } \\
\text { 4. More often than not } \\
\text { 5. Always }\end{array}$ \\
\hline $\begin{array}{l}\text { 2.4 How confident do you feel that } \\
\text { (along with others) you will be } \\
\text { able to bring change to your } \\
\text { community? }\end{array}$ & $\begin{array}{l}\text { 1. I never have confidence that I'll be able to bring change } \\
\text { 2. Very little of the time .... } \\
\text { 3. Sometimes yes, sometimes no... } \\
\text { 4. More often than not... } \\
\text { 5. I have complete confidence..... }\end{array}$ \\
\hline $\begin{array}{l}\text { 2.5 How much freedom do you } \\
\text { have to make your own } \\
\text { decisions about the things that } \\
\text { matter to you? }\end{array}$ & $\begin{array}{l}\text { 1. I have no freedom at all.... } \\
\text { 2. I have very little freedom } \\
\text { 3. I sometimes have freedom and sometimes not } \\
\text { 4. I have freedom most of the time } \\
\text { 5. I have complete freedom }\end{array}$ \\
\hline
\end{tabular}


Gaines - 89

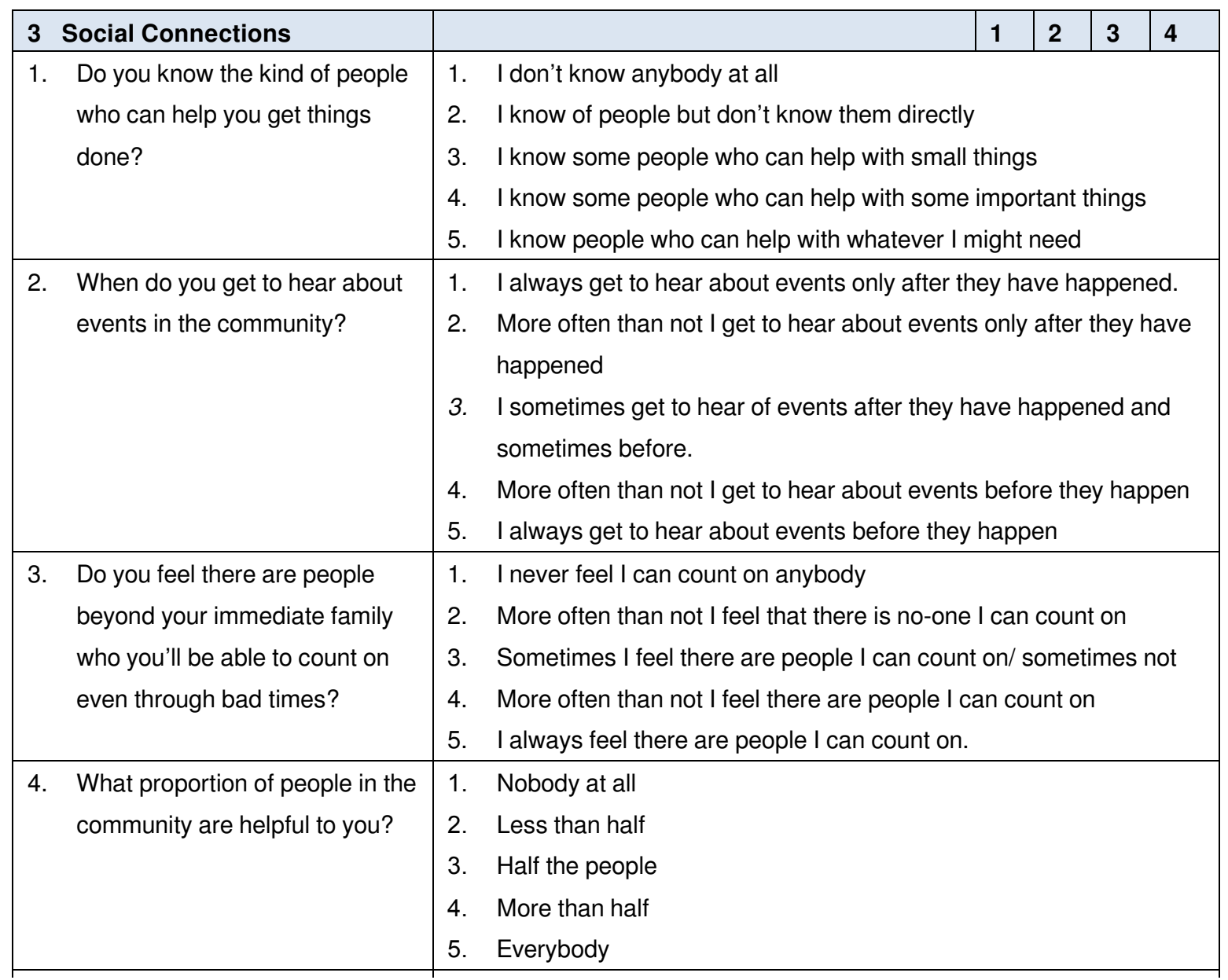




\begin{tabular}{|c|c|}
\hline \multicolumn{2}{|l|}{ 4. Close relationships } \\
\hline $\begin{array}{l}\text { When your mind/heart is } \\
\text { troubled/heavy, do you feel } \\
\text { there is someone that you can } \\
\text { go to? }\end{array}$ & $\begin{array}{l}\text { 1. Never } \\
\text { 2. Very little of the time } \\
\text { 3. Sometimes yes, sometimes no } \\
\text { 4. More often than not } \\
\text { 5. Always }\end{array}$ \\
\hline $\begin{array}{l}\text { 2. How happy are you with the } \\
\text { way people in your family } \\
\text { behave towards/treat you)? }\end{array}$ & $\begin{array}{l}\text { 1. Very unhappy } \\
\text { 2. Slightly unhappy } \\
\text { 3. Neither happy nor unhappy } \\
\text { 4. Slightly happy } \\
\text { 5. Very happy }\end{array}$ \\
\hline $\begin{array}{l}\text { 3. Even when others are around, } \\
\text { how often do you feel isolated } \\
\text { or alone? }\end{array}$ & $\begin{array}{l}\text { 1. I always feel isolated and alone even when there are others around } \\
\text { 2. Much of the time... } \\
\text { 3. Sometimes/sometimes not } \\
\text { 4. It is unusual for me to feel isolated and alone even when there are others } \\
\text { around } \\
\text { 5. I never feel isolated and alone }\end{array}$ \\
\hline $\begin{array}{l}\text { 4. How fairly do you feel the } \\
\text { responsibility for running the } \\
\text { household is shared between } \\
\text { you and other household } \\
\text { members? }\end{array}$ & $\begin{array}{l}\text { 1. Responsibility for running the household is not shared at all } \\
\text { 2. Responsibility for running the household is shared unfairly } \\
\text { 3. Responsibility ... is partly fair and partly unfair } \\
\text { 4. Responsibility .... is fair most of the time } \\
\text { 5. Responsibility for running the household is totally fair }\end{array}$ \\
\hline $\begin{array}{l}\text { 5. How much of the time do you feel } \\
\text { there is harmony in your home? }\end{array}$ & $\begin{array}{l}\text { 1. Never } \\
\text { 2. Very little of the time } \\
\text { 3. Sometimes yes, sometimes no } \\
\text { 4. More often than not } \\
\text { 5. Always }\end{array}$ \\
\hline
\end{tabular}




\begin{tabular}{|c|c|c|c|c|c|}
\hline 5. Physical and mental health & & 1 & 2 & 3 & 4 \\
\hline $\begin{array}{l}\text { 1. Do you ever have trouble } \\
\text { sleeping? }\end{array}$ & $\begin{array}{l}\text { 1. Always } \\
\text { 2. More often than not } \\
\text { 3. Sometimes yes, sometimes no } \\
\text { 4. Very little of the time } \\
\text { 5. Never }\end{array}$ & & & & \\
\hline $\begin{array}{l}\text { 2. How often do you feel too weak } \\
\text { for what you need to do? }\end{array}$ & $\begin{array}{ll}\text { 1. } & \text { Always } \\
\text { 2. } & \text { More often than not } \\
\text { 3. Sometimes yes, sometimes no } \\
\text { 4. Very little of the time } \\
\text { 5. Never }\end{array}$ & & & & \\
\hline 3. Do you suffer from tension? & $\begin{array}{l}\text { 1. Always } \\
\text { 2. More often than not } \\
\text { 3. Sometimes yes, sometimes no } \\
\text { 4. Very little of the time } \\
\text { 5. Never }\end{array}$ & & & & \\
\hline $\begin{array}{l}\text { 4. How much do you worry about } \\
\text { your health? }\end{array}$ & $\begin{array}{l}\text { 1. Always } \\
\text { 2. More often than not } \\
\text { 3. Sometimes yes, sometimes no } \\
\text { 4. Very little of the time } \\
\text { 5. Never }\end{array}$ & & & & \\
\hline $\begin{array}{l}\text { 5. How often do you have good } \\
\text { times? }\end{array}$ & $\begin{array}{ll}\text { 1. } & \text { Never } \\
\text { 2. Very little of the time } \\
\text { 3. Sometimes yes, sometimes no } \\
\text { 4. More often than not } \\
\text { 5. Almost all of the time }\end{array}$ & & & & \\
\hline
\end{tabular}


Gaines - 92

\begin{tabular}{|c|c|c|}
\hline \multicolumn{3}{|c|}{ 6. How you feel about yourself } \\
\hline 1 & $\begin{array}{l}\text { How well have you been able to } \\
\text { face life's difficulties? }\end{array}$ & $\begin{array}{l}\text { 1. Very badly } \\
\text { 2. Somewhat badly } \\
\text { 3. Sometimes well and sometimes badly } \\
\text { 4. Somewhat well } \\
\text { 5. Very well }\end{array}$ \\
\hline 2 & $\begin{array}{l}\text { How far do you feel you are able } \\
\text { to help other people? }\end{array}$ & $\begin{array}{l}\text { 1. I am never able to help other people } \\
\text { 2. Very little of the time am I able to help to people } \\
\text { 3. I am sometimes able to help people and sometimes not } \\
\text { 4. I am generally able to help other people } \\
\text { 5. I am always able to help other people }\end{array}$ \\
\hline 3 & $\begin{array}{l}\text { To what extent do you have } \\
\text { faith in yourself? }\end{array}$ & $\begin{array}{l}\text { 1. I have no faith in myself at all } \\
\text { 2. I often find it hard to have faith in myself } \\
\text { 3. Sometimes/sometimes not } \\
\text { 4. More often than not I have faith in myself } \\
\text { 5. I have complete faith in myself }\end{array}$ \\
\hline 4 & $\begin{array}{l}\text { To what extent do you tend to } \\
\text { doubt the decisions that you } \\
\text { have made? }\end{array}$ & $\begin{array}{l}\text { 1. I always doubt decisions that I have made } \\
\text { 2. More often than not I tend to doubt decisions... } \\
\text { 3. Sometimes/sometimes not } \\
\text { 4. It is unusual for me to ... } \\
\text { 5. I never doubt decisions that I have made }\end{array}$ \\
\hline 5 & $\begin{array}{l}\text { Looking to the future, how } \\
\text { confident do you feel that you } \\
\text { will be able to fulfil your } \\
\text { responsibilities? }\end{array}$ & $\begin{array}{l}\text { 1. Not at all (feel) } \\
\text { 2. Very little } \\
\text { 3. Sometimes/ sometimes not } \\
\text { 4. More often than not } \\
\text { 5. Totally confiden }\end{array}$ \\
\hline
\end{tabular}


Table 2.

Set of Items Measuring Dimensions of Inner Wellbeing, India Time 2

\begin{tabular}{|c|c|c|c|c|c|}
\hline 7. Values & & 1 & 2 & 3 & 4 \\
\hline $\begin{array}{l}1 \text { To what extent have you been } \\
\text { able to practise your religion in the } \\
\text { way you would like? }\end{array}$ & $\begin{array}{l}\text { 1. Not at all (feel) } \\
\text { 2. Very little } \\
\text { 3. Sometimes/ sometimes not } \\
\text { 4. Generally } \\
\text { 5. Absolutely }\end{array}$ & & & & \\
\hline $\begin{array}{l}\text { To what extent do you feel that life } \\
\text { has been fair for you? }\end{array}$ & $\begin{array}{l}\text { 1. Utterly unfair } \\
\text { 2. Generally unfair } \\
\text { 3. Neither fair nor unfair } \\
\text { 4. Generally fair } \\
\text { 5. Totally fair }\end{array}$ & & & & \\
\hline $\begin{array}{l}\text { How far would you say you feel } \\
\text { peace in your heart at the end of } \\
\text { the day? }\end{array}$ & $\begin{array}{l}\text { 1. Not at all (feel) } \\
\text { 2. Very little } \\
\text { 3. Sometimes/ sometimes not } \\
\text { 4. More often than not } \\
\text { 5. Very strongly (feel) }\end{array}$ & & & & \\
\hline $\begin{array}{l}\text { To what extent would you say that } \\
\text { you live in fear of harm from } \\
\text { witchcraft or evil powers? }\end{array}$ & $\begin{array}{l}\text { 1. Very strongly (feel) } \\
\text { 2. More often than not } \\
\text { 3. Sometimes/ sometimes not } \\
\text { 4. Very little } \\
\text { 5. Not at all (feel) }\end{array}$ & & & & \\
\hline $\begin{array}{l}5 \text { To what extent do you feel that life } \\
\text { has been good to you? }\end{array}$ & $\begin{array}{l}\text { 1. Very bad } \\
\text { 2. Bad } \\
\text { 3. Just ok } \\
\text { 4. Good } \\
\text { 5. Very good }\end{array}$ & & & & \\
\hline
\end{tabular}




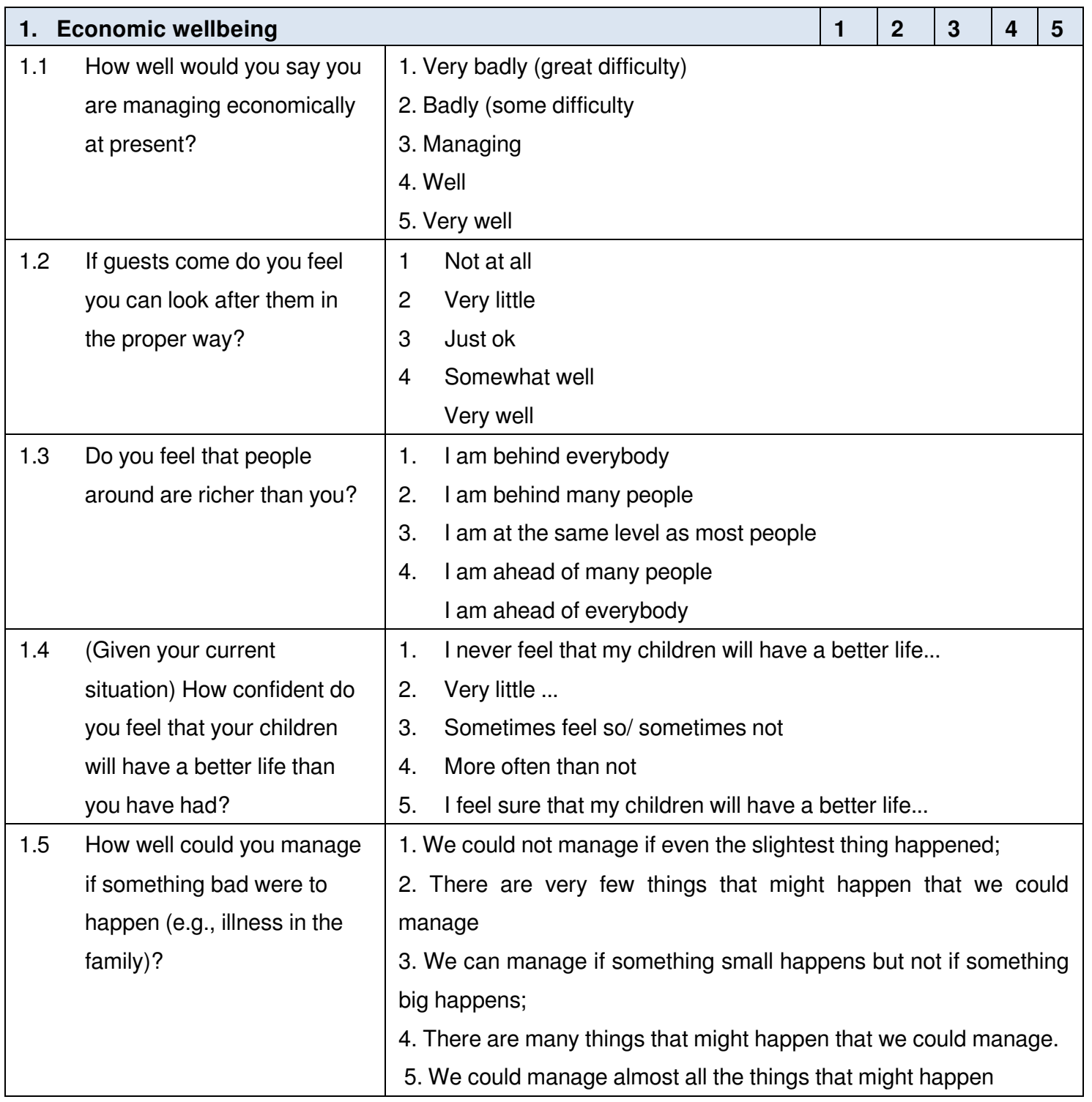


Gaines - 95

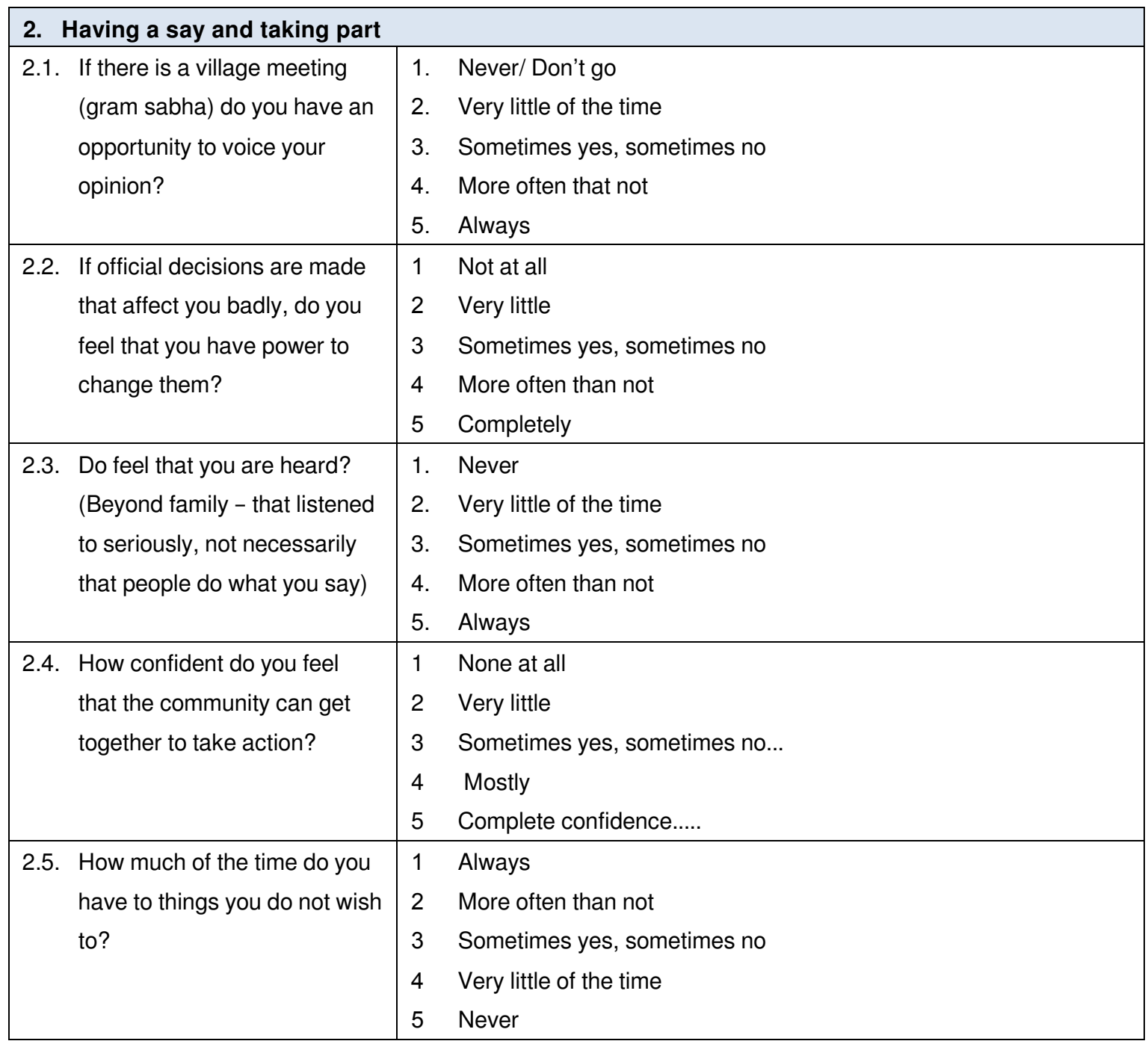


Gaines - 96

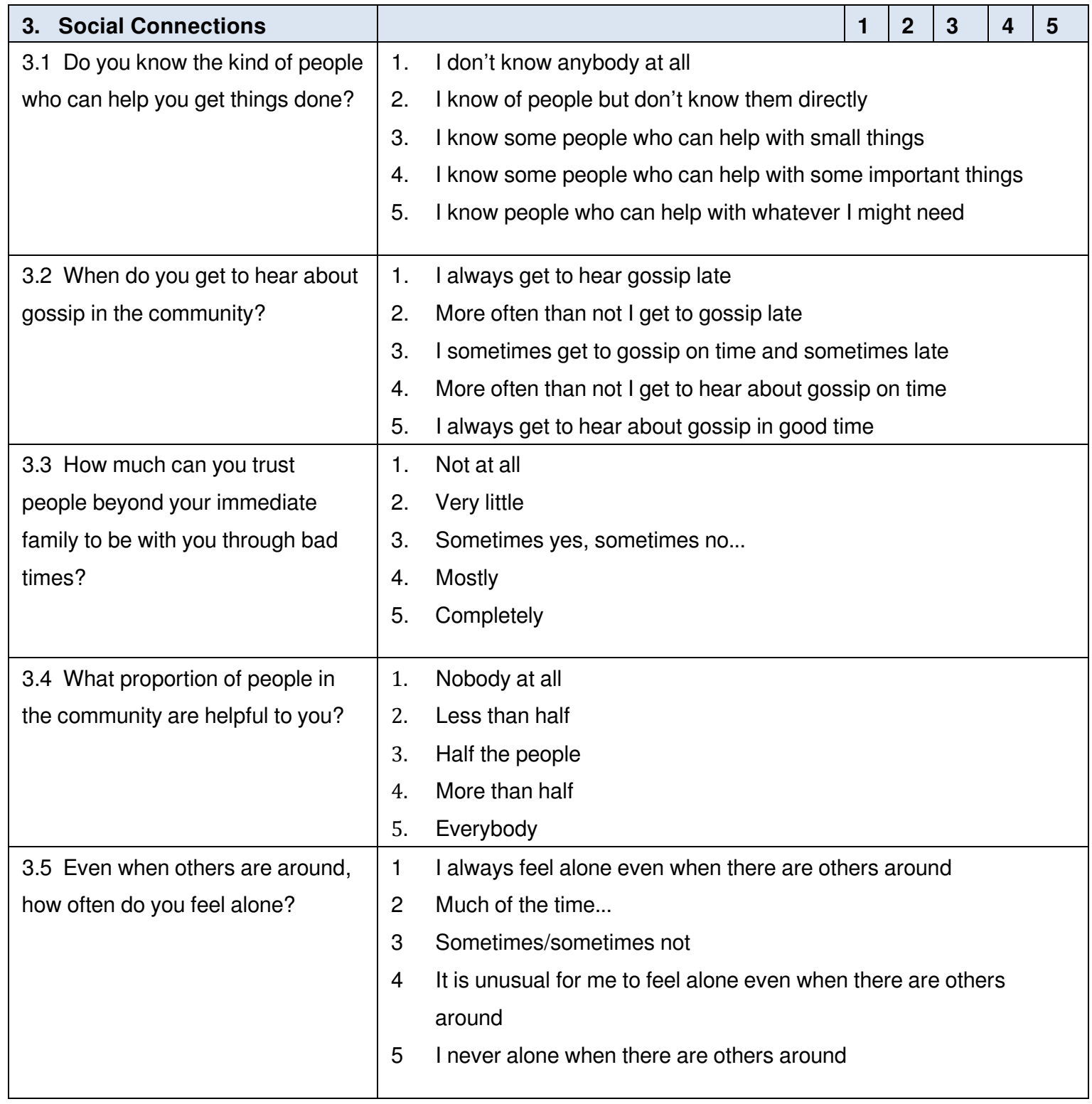


Gaines - 97

\begin{tabular}{|c|c|}
\hline 4. Close relationships & \\
\hline $\begin{array}{l}4.1 \text { How well do you get along } \\
\text { amongst yourselves? }\end{array}$ & $\begin{array}{l}\text { 1. Not at all } \\
\text { 2. Very little } \\
\text { 3. Sometimes yes, sometimes no... } \\
\text { 4. Mostly } \\
\text { 5. Completely }\end{array}$ \\
\hline $\begin{array}{l}4.2 \text { If there is a problem in your } \\
\text { family how easily can you sort it } \\
\text { out? }\end{array}$ & $\begin{array}{ll}\text { 1. } & \text { With great difficulty } \\
\text { 2. } & \text { With difficulty } \\
\text { 3. } & \text { Sometimes with difficulty, sometimes easily } \\
\text { 4. } & \text { Easily } \\
\text { 5. } & \text { Very easily }\end{array}$ \\
\hline $\begin{array}{l}\text { 4.3 When your mind/heart is } \\
\text { troubled/heavy, do you feel there is } \\
\text { someone that you can go to? }\end{array}$ & $\begin{array}{l}\text { 1. Not at all } \\
\text { 2. Very little } \\
\text { 3. Sometimes yes, sometimes no... } \\
\text { 4. Mostly } \\
\text { 5. Completely }\end{array}$ \\
\hline $\begin{array}{l}\text { 4.4 How much do people in your } \\
\text { house care for you? }\end{array}$ & $\begin{array}{l}\text { 1. Not at all } \\
\text { 2. Very little } \\
\text { 3. Sometimes yes, sometimes no... } \\
\text { 4. Mostly } \\
\text { 5. Completely }\end{array}$ \\
\hline $\begin{array}{l}4.5 \text { How uneasy are you made by } \\
\text { the amount of violence in your } \\
\text { home? }\end{array}$ & $\begin{array}{ll}\text { 1. } & \text { Completely } \\
\text { 2. } & \text { Mostly } \\
\text { 3. } & \text { Sometimes yes, sometimes no } \\
\text { 4. } & \text { Very little } \\
\text { 5. } & \text { Not at all }\end{array}$ \\
\hline
\end{tabular}

